\title{
Care of the Stillborn Body from the Perspective of Parents
}

\author{
Jui-Chiung Sun*
}

\section{Department of Nursing, Chang Gung University of Science and Technology, and Assistant Research Fellow, Linkou Chang Gung} Memorial Hospital, Taoyuan, Taiwan

\section{INTRODUCTION}

The care of the stillborn remains is an essential duty. One of the basic tasks of the medical staff is to respect the culture and religious belief valued by both individuals and family members [1]. Religious ceremony helps family members avoid chaos, keep calm, deal with disappointment, and heal trauma [2].

The parents no touching the body of the dead baby within the 8 hours in our study. According to Buddhist doctrine, a dead person should be kept from being moved or touched within the 8 hours following their death; otherwise, they would feel pain and fall into the abyss of evil; meanwhile, the living share Buddhist classics with the dead person so that their soul and spirit are led home. If their body were touched, their spirit would get lost and fail to return home.

Consequently, the soul would become a homeless one and would not be reincarnated [3]. In the face of religious beliefs, most Taiwanese would follow the societal, religious, and folk traditions. With parental love, all parents would send stillborn babies off with whatever they can offer and would hold all of the beneficial ceremonies for the dead, to help relieve their grief [4].

In Taiwanese culture and custom, children aged 12 or younger who die are regarded as the early dead. According to the taboos about early dead persons, no funerals would be held, and no sacrifices would be offered, and the elder family members should avoid touching the remains of the dead. Those who violate these taboos would cause the reluctant departure of the soul of the dead, and the soul would stay at home and bring the family misfortune. Moreover, the dead would fail to be reincarnated and would become a homeless specter $[4,5]$.

In Taiwan, most people would follow the traditional religious customs and social taboos. Rituals like worship for ancestors and the faith in spirits are reasons accepted by the public [4-6]. Parents' choosing not to have a look at their dead baby helps the parents handle their sorrow and guilt of losing the baby implicitly, with a reason accepted by the public, such as the consideration of following the cultural taboos. From another perspective, the parents who follow the customs and taboos are reluctant to discuss and have a look at their dead babies and touch their remains due to the taboos.

In Western countries, the strategies of helping alleviate sorrow include seeing, baptizing, and naming the child to help prevent pathological sorrow $[5,6]$. We found that the disposal of the remains of dead babies varies from culture to culture. According to the Taiwanese custom, the taboos have a different meaning and functions for parents than in western culture. The Taiwanese parents in the study, for instance, followed the taboo and chose not to see their dead babies.

They did it out of consideration for the child to reincarnate and to prevent family members from being harmed. Therefore, medical professionals need to respect the customs and taboos of the parents and, more importantly, they need to pay attention to the significance of the customs and taboos in the daily clinical care.

Thus, clinical care should be combined with the culture and customs of families, and the discussion on the preparation for the care of the remains should be held with parents at an appropriate time and in an appropriate place before such practices are needed. Additionally, a private space should be offered to the parents where they can express their feelings, share their experience, and have a discussion. After relevant discussion, all of the decisions made by the parents should be respected and supported by offering individualized nursing care.

\section{REFERENCES}

1. NCP (2013) Clinical Practice Guidelines for Quality Care, 3rd Edn. In.: National Consensus Project for Quality Palliative Care.

2. Kobler K, Limbo R, Kavanaugh K. Meaningful moments: the use of ritual in perinatal and pediatric death. MCN Am J Matern Child Nurs. 2017;32:288.

3. Olausson J, Ferrell BR. Care of the body after death. Clin J Oncol Nurs. 2013;17:647.

"Correspondence to: Jui-Chiung Sun, Department of Nursing, Chang Gung University of Science and Technology, and Assistant Research Fellow, Linkou Chang Gung Memorial Hospital, Taoyuan, Taiwan, Tel: 886-3-2118999; E-mail: 90006@mail.cgust.edu.tw

Receivd: December 03, 2018, Accepted: December 27, 2018, Published: January 02, 2019

Citation: Jui-Chiung Sun. Care of stillborn body from the perspective of parents. Clinics Mother Child Health. 2019;16:311.

Copyright: (C) 2019 Sun JC. This is an open-access article distributed under the terms of the Creative Commons Attribution License, which permits unrestricted use, distribution, and reproduction in any medium, provided the original author and source are credited. 
4. Wang C. An exploration of the encounter of grief therapy and Taiwan's mourning rituals and religious beliefs. J Life Death Stud. 2006;1:93.

5. Hsu M, Tseng Y, Kuo L. Transforming loss: Taiwanese women's adaptation to stillbirth. J Adv Nurs. 2002;40:387.
6. Sun JC, Rei W, Sheu SJ. Seeing or not seeing: Taiwan's parents' experiences during stillbirth. Int J Nurs Stud. 2014;51:1153. 